\section{ПАРТИЙНЫЕ ОРГАНЫ И ОБЩЕСТВЕННЫЕ ОРГАНИЗАЦИИ ТУВИНСКОЙ НАРОДНОЙ РЕСПУБЛИКИ В ГОДЫ ВЕЛИКОЙ ОТЕЧЕСТВЕННОЙ ВОЙНЫ}

\author{
Алдын-оол К. Канзай \\ Независимый исследователь, \\ Российская Федерация
}

\author{
COMMUNIST PARTY \\ ORGANS AND \\ NON-GOVERNMENTAL \\ ORGANIZATIONS IN \\ PEOPLE'S REPUBLIC \\ OF TUVA DURING \\ GREAT PATRIOTIC WAR
}

В статье рассматриваются основные направления, формы и методы работы партийно-государственных органов и общественных организаций Тувинской народной республики (ТНР), которые обеспечивали участие тувинского народа в Великой Отечественной войне Советского Союза. Автором приводятся факты, статистические материаль, высказывания государственных деятелей о формах и видах поддержки тувинского народа Советскому Союзу в борьбе против немецко-фашистских захватчиков. В качестве источников выступают сведения, опубликованные в научной литературе и содержащиеся в материалах Центрального государственного архива Республики Тыва.

Среди партийных мер называются: задачи по перестройке народного хозяйства на военный лад, поставленные на II пленуме ЦК ТНРП 26 июня 1941 г.; задачи организации массового производства лыж и предметов теплой одежды для Красной армии, увеличения поголовья скота и посевных площадей, развитие соревнования и ударничества, поставленных на III пленуме ЦК ТНРП 22 декабря 1941 г.; резолюция III сессии Малого Хурала ТНР 17 февраля 1942 г. о готовности тувинцев с ору-

\author{
Aldyn-ool K. Kanzai \\ Independent researcher, \\ Russian Federation
}

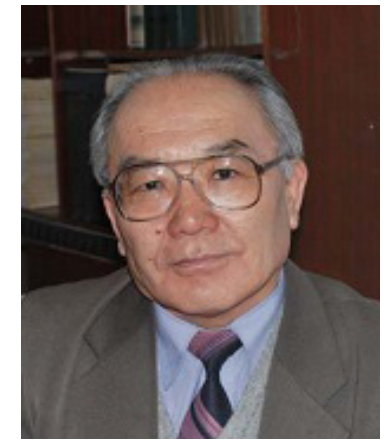

The article examines the main directions, forms and methods of work used by Revolutionary Party organs and non-governmental organizations of the People's Republic of Tuva (PRT) which helped ensure the participation of Tuvans in the Great Patriotic war of the USSR (WWII). To describe the forms and types of support the people of Tuva gave to the Soviet Union in its fight against the Nazi invaders, the author provides facts, statistics and quotations from Tuvan statesmen. These pieces of data come from both academically published sources and those found in the Central State Archives of the Republic of Tuva.

The steps and measures initiated by the Revolutionary Party include the program of wartime rebuilding of the economy (adopted at the 2nd plenum of the Central Committee of Tuvan National Revolutionary Party (CC TNRP), June 26, 1941); plans of mass production of skis and warm clothes for the Red Army, of an increase in livestock and crop field areas, of enhancing competitive work and introducing 'shock work' practices (adopted at 3rd Plenum of CC TNRP, December 22, 1941); the resolution on the readiness to enlist Tuvan youth in

Канзай Алдын-оол Кангаевич - кандидат исторических наук, независимый исследователь, Заслуженный работник образования Республики Тыва; г. Кызыл, Республика Тыва. Эл. адрес: igi@tigpi.ru Kanzai Aldyn-ool Kangaevich, Candidate of History, Independent Researcher, Honored Worker of Education, Republic of Tuva; Kyzyl, Republic of Tuva. E-mail: igi@tigpi.ru 
жием в руках встать под боевые знамена Красной Армии; постановление Совета Министров ТНР и ЦК ТНРП (июль 1942 г.) об организации военной подготовки граждан ТНР, о создании отрядов народного ополчения и др.

В годы войны в среде народных масс зародилось много форм помощи СССР. Наиболее массовым и результативным явилось всенародное движение за сбор средств в фонд обороны СССР. В том числе: отчисление средств, выделение охотничьей добычи, скота украинским колхозам, пшеницы и проса - в фонд обороны СССР и др. Инициативы шли от школьных коллективов, от ревсомольских организаций, от отдельных граждан.

Мобилизации трудящихся Тувы проходила в условиях иееленаправленной, повседневной разъяснительной, агитационно-массовой и организаторской работы партийно-государственных органов и общественных организаций ТНР. Руководящие органы отмечали и поддерживали патриотическое устремление коллективов и граждан: награждали граждан орденами и почетными грамотами. О передовиках писали в газетах и листовках, говорили на собраниях и митингах, ставили в пример.

Ключевые слова: Тувинская народная республика; Тува; тувинцы; история Тувы; Великая Отечественная война; тувинские добровольцы; коммунистические организации; общественные организации; СССР; мобилизация the Red Army, adopted by the 3rd session of the PRT's Small Khural, February 17, 1942; the joint order by the Cabinet of Ministers of PRT and the CC TNRP to set up a system of war training for the citizens of PRT and a national militia, adopted in July 1942; etc.

The war years gave rise to a lot of grassroots initiatives of supporting the USSR, the most massive and fruitful among them being the movement to raise the money for the USSR's Defense Fund. Donations included money transfers, providing spoils of the chase and livestock to the collective farms of Ukraine, and wheat and millet, to the Defense Fund. Among the donors were schools, Revolutionary Youth cells and private individuals.

Mobilization in Tuva was accompanied by dedicated everyday organizational, explanatory and agitational work of the organs of the party and state, as well as non-governmental organizations. The leaders of the PRT supported the patriotic moves of both collectives and individuals, awarding orders, medals and diplomas of merit to those most active. Best workers were commended in papers and leaflets, mentioned at meetings and rallies, and generally treated as exemplary citizens.

Keywords: People's Republic of Tuva; Tuva; Tuvans; history of Tuva; Great Patriotic war; World war II; Tuvan volunteers; communist party organizations; non-governmental organizations; USSR; mobilization

\section{Введение}

Участие тувинского народа в Великой Отечественной войне на стороне его надежного союзника и защитника - СССР, оказание Красной Армии посильной политической, материальной поддержки и помощи, отправка на фронт воинов-добровольцев стало значительным событием в истории Тувы. Оно характеризовало укрепление и углубление тувинско-советских отношений, выражало высокую степень доверия и сближения братских народов, что логически завершилось принятием Тувы в состав СССР в 1944 г., еще до завершения войны с фашистской Германией.

Для некоторой части людей нынешнего поколения, особенно молодежи, не всегда понятны условия, предпосылки и мотивы, приведшие к такому тесному сотрудничеству. Это непонимание можно емко выразить одним вопросом: почему небольшой тувинский народ столь активно, без всякого сомнения и промедления включился в борьбу с фашистскими захватчиками? 
Чтобы ответить на него, необходимо учесть ряд обстоятельств.

Во-первых, тувинско-русские отношения развивались по нарастающей с XIX века и получали новые импульсы в важные исторические моменты начала XX века: в 1914 г. - во время установления протектората России над Урянхайским краем, а также в 1921 г., когда Тува смогла провозгласить свою государственность при поддержке советской власти. И в период становления Тувинской народной республики (ТНР) связи между народами приобрели многосторонний союзнический характер, включая политическую, экономическую, культурную и иные сферы жизни.

Во-вторых, вся государственная система и общественные организации ТНР в годы войны составляли единый механизм, имеющий ясную цель и программу действий, призванной оказывать всестороннюю помощь Советскому союзу.

B-третьих, благодаря слаженной работе партийно-государственных органов и общественных организаций ТНР в стране удалось создать атмосферу сплоченности и организованности всех слоев населения, дух высокого патриотизма во имя победы над фашизмом.

B-четвертых, немалую роль также играло понимание тувинцами, угнетавшимися веками другими государствами, что угроза нависла не только над северным соседом, но и над ними самими.

Участию тувинского народа в войне посвящена обширная научная литература. Оно подробно отражено в «Очерках Тувинской организации КПСС» (Очерки истории ..., 1975), во II томе «Истории Тувы» (История Тувы, 2007: 374-394), в книге «Великая Отечественная война в исследованиях ученых, воспоминаниях и письмах фронтовиков» (Великая ..., 2011), «Книга Памяти. Республика Тыва» (Книга памяти ..., 1995) и других исторических источниках. Изучением этой темы занимались Ю. Л. Аранчын, В. А. Дубровский, Н. М. Моллеров и другие ученые. Научную ценность представляют работа В. А. Дубровского «Участие Тувы в Великой Отечественной войне Советского Союза», включающая 46 официальных документов (Дубровский, 1960), сборник, подготовленный Архивным агентством и ЦГА РТ «Тува в годы Великой Отечественной войны в документах» (Тува в годы ..., 2005), в котором собраны около 150 различных архивных документов, писем, телеграмм, текстов сообщений в печати, заявлений граждан с просьбой отправить их на фронт, рапортов работников сельскохозяйственных, промышленных предприятий, организаций и учреждений о выполнении ими планов и социалистических обязательств по оказанию помощи Красной Армии. Из всех этих материалов четко видна огромная разъяснительная, политико-воспитательная и организаторская работа партийно-государственных органов: ЦК ТНРП, Малого Хурала трудящихся и Совета Министров ТНР, их местных подразделений и общественных организаций.

Анализ содержания принимавшихся решений и проводившихся мероприятий показывает, что они отвечали обстановке военного времени, отличались 
конкретностью постановки задач, выражающих коренные интересы страны, затрагивали умы и сердца людей, имели большую мобилизующую роль. В заявлениях, рапортах, письмах и других архивных материалах отражены дела и заботы наших земляков, их тревоги и настроения в годы военных испытаний. Основополагающим документом, определившим программу действий тувинского народа на протяжении всей войны и отразившим его волю и решимость, является принятая в день начала войны Декларация X Великого Хурала трудящихся ТНР о готовности всеми силами и средствами участвовать в борьбе советского народа против фашистского агрессора до окончательной победы над ним (Тува в годы ..., 2005: 8-9).

В данной статье мы рассмотрим основные направления, формы и методы работы партийно-государственных органов и общественных организаций ТНР, которые обеспечивали участие тувинского народа в Великой Отечественной войне Советского Союза.

\section{Партийные меры}

Состоявшийся 26 июня 1941 г. II пленум ЦК ТНРП наметил ближайшую задачу по перестройке народного хозяйства на военный лад. Было решено досрочно перевыполнить план ТНР перед СССР по экспорту, уменьшить импорт промышленных товаров и других материально-технических средств из СССР. Указывалось на необходимость расширения и создания новых промышленных предприятий, увеличения производства товаров широкого потребления и продовольствия из местного сырья, соблюдения строжайшего режима экономии, изыскания ресурсов повышения продуктивности животноводства и земледелия. Начать сбор средств на приобретение трех самолетов, а также отбор не менее 5 тыс. голов лошадей для Красной Армии. Особо уделялось внимание на усиление Народно-революционной Армии, увеличение ее численного состава вдвое, широкое развертывание оборонно-массовой и физкультурно-спортивной работы (Центр архивных документов партий и общественных организаций Центрального Государственного архива Республики Тыва - ЦАДПОО ЦГА РТ. Ф. 1. ОП. 1. Д. 2942. Л. 1-4).

III пленум ЦК ТНРП (22 декабря 1941 г.) постановил с начала 1942 г. организовать массовое производство лыж, полушубков, валенок и рукавиц для Красной Армии. Ставилась задача довести поголовье скота республики до 1700 тыс. голов, увеличить посевные площади на $32,3 \%$. Развивать соревнование и ударничество, чтобы оно стало делом всех рабочих и служащих, поднять его до уровня стахановского движения (там же. Л. 5-11).

III сессия Малого Хурала ТНР (17 февраля 1942 г.), учитывая желание многих граждан республики непосредственно участвовать в боях против немецко-фашистских захватчиков, приняла резолюцию (текст был опубликован в газете 
«Тувинская правда» от 2 марта 1942 г.), в которой содержалась такая фраза: «От имени всего тувинского народа сессия заявляет Правительству СССР и всему советскому народу о готовности тувинцев с оружием в руках встать под боевые знамена Красной Армии на борьбу против общего врага, на борьбу за честь, свободу и независимость народов великого СССР и ТНР».

Партийно-государственные органы ТНР обращали особое внимание укреплению Народно-революционной армии и военной подготовке населения. В июле 1942 г. Совет Министров ТНР и ЦК ТНРП приняли постановление об организации военной подготовки граждан ТНР, о создании отрядов народного ополчения (ЦАДПОО ГА РТ. Д. 2509. Л. 179). В конце декабря 1942 г. ЦК ТНРП вновь вернулся к этому вопросу и отметил серьезные недостатки в выполнении предыдущих решений. Военному Министерству поручено, чтобы к 1 мая 1943 г. все граждане от 16 до 50 лет прошли военное обучение по 110 часовой программе (там же. Д. 2653. Л. 136).

IV пленум ЦК ТНРП (11 июля 1942 г.) отметил некоторые сдвиги в военной подготовке населения. К этому времени ее было охвачено свыше 19 тыс. человек, из которых 7 тыс. закончили обучение по 110 часовой программе и программу по специальной подготовке (там же. Д. 2644. Л. 13).

Принятые меры по укреплению армии и военной подготовке граждан дали основание ЦК ТНРП и Правительству ТНР сообщить Народному Комиссариату СССР 9 сентября 1941 г., что личный состав народно-революционной армии увеличивается до 1000 человек. Считая себя мобилизованной для защиты Союза ССР, ТНР готова выступить на борьбу с немецким фашизмом своими вооруженными силами. Она может поставить под ружье 6-7 тыс. человек, не считая 2-2,5 тысяч советских граждан, живущих в ТНР (Центральный государственный архив Республики Тыва - ЦГА РТ. Ф. 93. Оп. 1. Д. 246. Л. 4). Действительно в рядах народного ополчения прошли военную подготовку и получили воинские специальности сотни юношей, а десятки девушек прошли курсы медицинских сестер, связистов, снайперов, многие из них впоследствии были зачислены добровольцами в ряды Советской Армии.

\section{Общественное движение}

Благодаря целенаправленной и настойчивой работе партийно-государственных органов и общественных организаций ТНР в годы войны в среде народных масс зародилось много форм помощи СССР в борьбе с немецкими захватчиками. Наиболее массовым и результативным явилось всенародное движение за сбор средств в фонд обороны СССР.

Широкую поддержку получила инициатива передовых коллективов г. Кызыла и хошунов - каждому работающему предлагалось отчислить средства в фонд обороны СССР. ЦК ТНРП одобрил начинания охотников Тоджинского и 
Пий-Хемского хошунов внести в фонд помощи фронту всю добычу первого дня охоты, а также жителей пос. Федоровка Каа-Хемского хошуна о шефстве над одним из колхозов Киевской области и оказании помощи в восстановлении животноводства, выделив для этой цели 109 голов скота (Дубровский, 1960: 292-263). В 1942 г. труженики тожземов, колхозов и госхозов засеяли около 1 тыс. га пшеницы и проса в фонд обороны СССР. Урожай с этой площади был отгружен в Советский Союз. С этих пор посевы в фонд обороны проводились ежегодно и во все возрастающих масштабах (Очерки истории ..., 1975: 141). Члены сельхозартели им. Кочетова решили отчислить в счет третьего эшелона подарков с каждого заработанного в текущем году трудодня по 1 килограмму пшеницы - это составляет 360 пудов (Тува в годы ..., 2005: 68). Учащиеся Харальской советской школы собрали в помощь Красной Армии подарков на 128 акша 70 коп. (там же: 40). Ревсомольские организации собрали средств на постройку танка «Молодежь Тувы», а также постановлением ЦК ТНРП производился сбор средств на постройку авиаэскадрильи «Тувинская Народная Республика». Таким образом, оказание помощи Советскому Союзу и сбор средств в фонд обороны СССР стали всенародным делом, в котором бескорыстно участвовало практически все население ТНР, включая мужчин и женщин, стариков и школьников. Чтобы приблизить победу, люди отдавали на фронт все, что имели: скот, теплые вещи, продукты питания, свои сбережения. Красные обозы с подарками непрерывно поступали со всех концов Тувы.

Президиум Малого Хурала, Совет Министров ТНР и ЦК ТНРП 20 февраля 1942 г. приняли постановление об отправке 25 вагонов подарков для Красной Армии, опубликованное в «Тувинской правде» от 23 февраля 1942 г. Сбор подарков проводился настолько быстро и повсеместно, что уже 5 апреля 1942 г. на фронт был отправлен первый эшелон подарков из 53 вагонов, а 15 августа - второй эшелон подарков из 52 вагонов (ЦАДПОО ЦГА РТ. Д. 2745. Л. 5). В дальнейшем - в декабре на фронт был отправлен третий эшелон подарков из 106 вагонов, в августе 1943 г. - четвертый эшелон из 126 вагонов, и наконец, в декабре 1943 г. - пятый эшелон подарков из 52 вагонов. Всего 389 вагонов подарков (там же. Д. 2751. Л. 24-25).

\section{Агитационная работа}

Характерной особенностью работы руководящих органов Тувы в годы войны было умение своевременно замечать и поддержать патриотическое устремление коллективов и граждан. Президиум Малого Хурала ТНР, высоко оценивая их вклад во всенародное движение по оказанию помощи фронту, систематически награждал граждан орденами и Почетными грамотами. Так, 31 декабря 1941 г. были награждены передовики производства, 30 марта 1942 г. - 4 передовых колхоза и 15 их членов, в декабре 1942 г. - большая группа тружеников 
села за успехи в развитии животноводства (Тува в годы ..., 2005: 27-28, 41-43, 71-72). О передовых людях постоянно писали в газетах и листовках, о них говорили на собраниях и митингах, с них брали пример другие.

Важнейшая роль в мобилизации трудящихся Тувы на помощь и поддержку Советской страны в годы войны принадлежит целенаправленной, повседневной разъяснительной, агитационно-массовой и организаторской работе партийно-государственных органов и общественных организаций ТНР. Уделяя неослабное внимание этим вопросам, неоднократно их обсуждая, всячески поддерживая начинания и инициативы людей, решительно устраняя недостатки и упущения, они добивались повышения политической и трудовой активности масс, осознание ими общности задач в борьбе с немецким фашизмом, необходимости укрепления дружбы и сотрудничества с народами СССР.

Вопросы партийно-политической и агитационно-массовой работы были обсуждены на V пленуме ЦК ТНПР (31 октября - 2 ноября 1942 г.). Пленум потребовал от партийных организаций усилить внимание к политической учебе партийцев и агитмассовой работе среди населения, организовать повсеместно кружки по изучению истории ВКП(б), Программы и Устава ТНРП, снабдить все красные уголки необходимой литературой, как гласила публикация в республиканском журнале «Под знаменем Ленина-Сталина» (№ 2, 1942 г.).

Состояние партийно-организационной работы было рассмотрено на VII пленуме ЦК ТНРП (февраль 1944 г.). Он принял постановление, предусматривающее укрепление первичных партийных организаций, усиление партийного руководства общественными организациями, работы за кадрами (журнал «Под знаменем Ленина-Сталина». № 1-2, 1944 г.). В целом же в годы войны большая разъяснительная работа среди населения велась агитпропгруппами ЦК партии, действовал 631 агитколлектив с 1679 агитаторами.

Широкий размах получила лекционная пропаганда. Проводниками политики партии становились культпросветучреждения, деятели литературы и искусства. Действенное влияние на сознание людей оказывали боевые призывы и плакаты: «Все для фронта, все для Победы!», «Подчиним всю жизнь страны задачам полного разгрома врага!», «Режим экономии - закон военного времени», «Что ты сделал для фронта?» и т. д. Эффективным средством партии по мобилизации трудящихся на решение задач военного времени была периодическая печать: газеты «Шын», «Тувинская правда», «Арэве шыны», политико-экономический журнал «Под знаменем Ленина-Сталина», а также радиовещание.

Важной формой политической работы явились многочисленные митинги боевой солидарности с советским народом. В письмах, телеграммах и резолюциях в адрес партийных и государственных органов СССР выражалась горячая поддержка борьбы советского народа с немецким агрессором. Так, в письме 1942 г. говорилось: «... суровая обстановка побуждает тувинцев с особой силой 
сознавать свою кровную неразрывность с жизнью и борьбой великого русского народа, всех народов СССР... Каждый день, каждый час беспрерывно и неустанно наш народ будет оказывать и увеличивать материальную помощь за свободу и независимость народов СССР и тувинского народа» (Очерки истории ..., 1975: 136-138).

Искренние чувства симпатии, доверия и признательности у тувинского народа вызывали у высшего руководства партии и правительства, министерств и ведомств СССР, командиров и бойцов Красной Армии каждое сообщение об оказании им моральной, материальной поддержки и помощи Советскому Союзу, Красной Армии. Особенно вдохновляющим, мобилизующим и многозначительным были крылатые слова, выраженные в телеграмме в связи с 20-летием ТНР 13 августа 1941 г., Председателем СНК СССР, Верховно-главнокомандующим Вооруженными силами СССР И. В. Сталина: «Победа советского народа будет также победой братского тувинского народа». Всего им было послано пять телеграмм и благодарностей тувинскому народу.

О тесных связях и доверительных отношениях советского и тувинского народов говорят такие факты. В. М. Молотов, М. И. Калинин, А. И. Микоян, А. Я. Вышинский, Г. К. Жуков, заместители НКИД, министры и другие отечественные работники в годы войны многократно встречались с партийно-государственными руководителями ТНР, дипломатическими представителями ТНР в СССР, а также многими делегациями Тувы.

29 декабря 1942 г. тувинская делегация посетила заместителя Наркома иностранных дел В. Г. Деканозова, который начал встречу с выражения благодарности за помощь фронту. По вопросу об участии тувинцев в боевых действиях он сказал, что пока силы поберечь до того момента, когда они могут понадобиться. Он подчеркнул: «Война Советского Союза с гитлеровской Германией показала большую сплоченность тувинского и советского народов и горячие симпатии тувинского народа к СССР... Тувинский народ проявляет такие невиданные в истории чувства симпатии и дружбы, воплощающиеся в братской помощи, что даже некоторые советские республики не проявляли такого энтузиазма. Это есть результат большой работы партии и правительства ТНР» (ЦГА РТ. Ф. 92. Оп. 1. Д. 283. Л. 4-6; см. также: Моллеров, 2010: Электр. ресурс).

Партийно-государственные органы ТНР, выражая волю и желание граждан, заявляли советскому руководству о готовности принять непосредственное участие в боевых сражениях на фронтах войны. Однако положительное решение вопроса затягивалось. 19 апреля 1943 г. секретарь ЦК ТНРП Салчак Тока, председатель Президиума Малого Хурала ТНР Хертек Анчима и председатель Совета Министров ТНР Сарыг-Донгак Чымба обратились с письмом лично к И. В. Сталину, где опять поставили вопрос об отправке на фронт тувинских добровольцев в количестве 400-500 человек (Тува в годы ..., 2005: 94-96). 
И только через некоторое время Советское правительство уведомило руководство ТНР о своем решении разрешить тувинским добровольцам влиться в ряды действующих на фронте частей Красной Армии. Это известие было воспринято тувинским народом с радостью и воодушевлением как большое доверие советского руководства.

20 мая 1943 г. на фронт отправилась группа тувинских танкистов в составе 11 человек, которые героически сражались за освобождение Украины, Молдавии, Румынии, Венгрии и Чехословакии. 1 сентября того же года состоялись проводы на фронт 209 добровольцев-кавалеристов. Они внесли большой вклад в освобождении городов Ровно и Дубно, других населенных пунктов Украины от немецко-фашистских оккупантов. Советское правительство высоко оценило героизм, отвагу и мужество тувинских добровольцев, наградив 67 из них орденами и медалями СССР. 135 добровольцев награждены орденами и медалями ТНР (Очерки истории ..., 1975: 149). Активное участие тувинских добровольцев в Великой Отечественной войне стало логическим итогом всей работы партийногосударственных органов и общественных органов ТНР по оказанию моральной, материальной поддержки и помощи Советскому Союзу и Красной Армии.

По уточненным данным, всего за годы войны тувинский народ направил в помощь Красной Армии 5 эшелонов или 389 вагонов подарков на сумму более 10 миллионов акша или 35 миллионов рублей, 50 тысяч боевых лошадей, 52 тысячи пар лыж, 10 тысяч полушубков, более 16 тысяч пар валенок, 19 тысяч пар рукавиц. На эти цели были переданы весь золотой запас ТНР и все добытое за годы войны золото. Только для освобожденных от оккупации сел Украины было передано около 30 тыс. коров (Великая Отечественная война ..., 2011: 16). Тува в годы войны шефствовала над двумя военными госпиталями и пятью детскими домами Красноярского края (ЦАДПОО ЦГА РТ. Ф. 1. ОП. 1. Д. 2935. Л. 48).

\section{Заключение}

Оценивая работу партийно-государственных и общественных организаций в годы войны напомним, что она давала не только положительные результаты, но и сталкивалась с серьезными трудностями. Перестройка работы народного хозяйства на военный лад шла нелегко. Не всегда в полном объеме выполнялись принятые решения по развитию сельского хозяйства, промышленности и социальной сферы. Срывались задания по производству некоторых видов оборонных заказов. Приходилось внедрять новые формы на производстве работу без отпусков и выходных, с удлиненным графиком. Большие усилия направлялись на укрепление организованности, трудовой дисциплины, усилению режима экономии. Многие кадры не были готовы работать в условиях военного времени, некоторые из них не выдерживали повышенных требований к 
ним. Принимались жесткие меры к тем, кто не справлялся с порученным делом. Благодаря терпеливому и настойчивому подходу к этим вопросам со стороны руководителей, опираясь на наиболее передовую и сознательную часть граждан, широкому внедрению советского опыта политической, организаторской и хозяйственной работы, удавалось значительно минимизировать последствия этих негативных явлений.

В заключении отметим, что добровольное участие тувинского народа в Великой Отечественной войне является историческим событием в его жизни, в ходе которого, несмотря на жертвы, невзгоды и страдания, проявились такие качества как честь, долг и достоинство, умение работать и воевать, бескорыстно придти на помощь, быть верным своему союзнику. Оно возвысило маленький народ перед лицом народов СССР и мировой общественности. Совместная борьба против гитлеровской Германии очень тесно сблизила советский и тувинский народы во всех направлениях жизни. Именно этот фактор стал решающим и закономерным в деле вхождения Тувы в состав СССР в 1944 году.

\section{СПИСОК ЛИТЕРАТУРЫ}

Великая Отечественная война в исследованиях ученых, воспоминаниях и письмах фронтовиков (2011) : материалы круглого стола, посвященного 65-летию Победы / редколл.: К. А. Бичелдей и др. Кызыл: Тип. КЦО «Аныяк». 248 с.

Дубровский, В. А. (1960) Участие Тувы в Великой Отечественной войне Советского союза // Ученые записки ТНИИЯЛИ. Вып. VIII. Кызыл. С. 272-308.

История Тувы (2007) / под ред. В. А. Ламина. Новосибирск : Наука. 427 с.

Книга памяти. Республика Тува (1995). Кызыл: Тувинское книжное издательство. 176 с.

Моллеров, Н. М. (2010) Советско-тувинское содружество в годы Великой Отечественной войны СССР против фашистской Германии [Электронный ресурс] // Новые исследования Тувы. № 2. URL: https://nit.tuva.asia/nit/article/view/527 (дата обращения: 12.08.2017).

Очерки истории Тувинской организации КПСС (1975) / [В. Ч. Очур, О. А. Толгар-оол, Ю. Л. Аранчын и др.] ; [ред. коллегия: Г. Ч. Ширшин (отв. ред.) и др.]. Кызыл : Тувин. кн. изд-во. 405 с.

Тува в годы Великой Отечественной войны в документах (2005) / отв. ред. Т. А. Бондаренко и др. Кызыл: Тув. книжн. изд-во. 231 с. 


\section{REFERENCES}

Velikaia Otechestvennaia voina $v$ issledovaniiakh uchenykh, vospominaniiakh $i$ pis'makh frontovikov [The Great Patriotic war in historical research, memoirs and letters from the battlefront] (2011) : Proceedings of the roundtable dedicated to the 65th anniversary of the Victory / K. A. Bicheldei (ed.) et al. Kyzyl, Tip. KTsO «Anyiak». 248 p. (In Russ.).

Dubrovskii, V. A. (1960) Uchastie Tuvy v Velikoi Otechestvennoi voine Sovetskogo soiuza [Tuva's participation in the Great Patriotic war of the Soviet Union]. Uchenye zapiski TNIIIaLI, vol. VIII. Kyzyl. Pp. 272-308. (In Russ.).

Istoriia Tuvy [The History Of Tuva] (2007) / ed. by V. A. Lamin. Novosibirsk, Nauka. 427 p. (In Russ.).

Kniga pamiati. Respublika Tuva [The book of memory. The Republic Of Tuva] (1995). Kyzyl, Tuvinskoe knizhnoe izdatel'stvo. 176 p. (In Russ.).

Mollerov, N. M. (2010) Sovetsko-tuvinskoe sodruzhestvo v gody Velikoi Otechestvennoi voiny SSSR protiv fashistskoi Germanii [Soviet-Tuvan fellowship during the Great Patriotic War of USSR against Nazi Germany]. The New Research of Tuva, no. 2 [online] Available at: https://nit.tuva.asia/nit/article/view/527 (access date: 12.08.2017). (In Russ.).

Ocherki istorii Tuvinskoi organizatsii KPSS [Essays on the history of Tuvan branch of the CPSU] (1975) / [V. Ch. Ochur, O. A. Tolgar-ool, Iu. L. Aranchyn et al., editorial board: G. Ch. Shirshin (ed.) et al.]. Kyzyl, Tuvin. kn. izd-vo. 405 p. (In Russ.).

Tuva $v$ gody Velikoi Otechestvennoi voiny $v$ dokumentakh [Tuva during the Great Patriotic war: in documents] (2005) / ed. by T. A. Bondarenko et al. Kyzyl, Tuv. knizhn. izd-vo. 231 p. (In Russ.).

Submission date: 07.10.2017.

\section{Для циитирования:}

Канзай А. К. Партийные органы и общественные организации Тувинской народной республики в годы Великой Отечественной войны [Электронный ресурс] // Новые исследования Тувы. 2017, № 4. URL: https://nit.tuva.asia/nit/article/view/737 (дата обращения: дд.мм.гг.). DOI: 10.25178/nit.2017.4.2

\section{For citation:}

Kanzai A. K. Communist Party Organs and Non-governmental Organizations in People's Republic of Tuva during Great Patriotic war. The New Research of Tuva, 2017, no. 4 [on-line] Available at: https://nit.tuva.asia/nit/article/view/737 (accessed: ). DOI: 10.25178/ nit.2017.4.2 